$\xi=-1$

\title{
Application of ferric-silicon coagulant-flocculant of electric steel smelting slag for leachate treatment of communal solid waste landfills
}

\author{
T.A. Vasilenko*, A.A. Koltun \\ ${ }^{1}$ Belgorod Shukhov State Tecnological University, 46 Kostyukova St., Belgorod, 308012, Russia \\ *Email: land-vna78@list.ru
}

\begin{abstract}
In the Russian Federation the most common way of disposal of waste products is landfill. One of its drawbacks is the formation of highly contaminated filtration water. It was made an attempt to treat the leachate with a ferric coagulant-flocculant obtained from the electric steel smelting slag after the acid treatment with hydrochloric acid (the modification time of $1.5 \mathrm{~N} \mathrm{HCl}$ at $40{ }^{\circ} \mathrm{C}$ is no more than 1 hour). To improve the treatment efficiency of highly contaminated leachate it was analysed a simultaneous application of the obtained coagulant-flocculant and conventional coagulants $\mathrm{Al}\left(\mathrm{SO}_{4}\right)_{2}$ and ferric chloride). It was shown a decrease in the values of the chemical oxygen demand (COD) by $94.4 \%$, the color of the leachate by (91.3\%). It was studied the physical and chemical properties of the filtration waters of the waste disposal landfill, as well as the dependence of the formation of the precipitable sediment volume on the portion of the injected coagulants and flocculant.
\end{abstract}

Keywords: Coagulants - Flocculants, Filtration Water, Leachate Landfills, Sewage Treatment, Electric Steel Smelting Slag.

\section{Introduction}

Electric steel smelting slags are technogenic wastes of the metallurgical production. They are used as an additive in the production of iron ore pellets, protective composite and building materials, slag-alkali binders for pouring crush-rock pad on roads etc. [1-4]. The principles of microbiological technology of extracting valuable components from ash-slag heaps [5] have been developed. But in practice, the use of slags is an undetermined environmental problem. There have been published works in which the studies have been carried out on the use of metallurgical waste products as reagents, coagulants or flocculants without a modification or after their activation for waste water treatment from heavy metals [6-10]. The ferric-containing coagulant is obtained from the waste pickling solutions by oxidation with sodium hypochlorite [11].

Filtration waters are formed while burial at communal solid waste disposals. The exploitation of waste disposals is accompanied by the formation of filtration waters with an increased content of pollutants due to moisture and biochemical decomposition of wastes, atmospheric precipitation. In the Russian Federation, the disposal of wastes is the predominant way of disposal. In the Russian Federation since 2018 the disposal without extracting useful components from waste will be prohibited. In Japan about $80 \%$ of the communal wastes is burnt and this value is increasing, because the search for new sites for final disposal has become difficult [12] In Germany wastes disposal has been banned since 2005, therefore it was introduced a selective wastes collection, sorting and incineration of non-recycled residues. The disadvantage of this incineration is the constant monitoring of the cleaned air for the presence of toxic compounds, including. dioxins [13].
For filtration waters there should be a system for collection and drainage of the leachate, which includes a drainage system (or drainage units), a gravity flow of drains from the drainage system to the treatment plant. For averaging the composition of the leachate, a control and regulating reservoir is provided, which has an anti-filtration shield made of certified materials (geotextiles and geomembranes) [14]. The complexity of the composition of the filtration water explains the fact that in practice purification is practically not carried out, since in each specific case it is required to select equipment that combines mechanical, physical and chemical, and biochemical processes.

It has been developed a hybrid technology for filtration water treatment, which combines a membrane technology with electrochemical methods. The use of this technology can reduce the consumption of coagulants, flocculants [15]. Due to the significant amounts of the leachate the operating enterprise has to conduct: monitoring its composition, infiltration control, as well as the sewers purifications. The danger of ingress of the leachate into the groundwater is very high.

The authors suggest a block scheme for the filtration cleaning unit, which includes: a mechanical filter, anaerobic digestion, electric and chemical oxidation, reagent treatment, sedimentation, membrane ultrafiltration, reverse osmosis, post-treatment by sorption, ultraviolet disinfection $[16,17]$. The technology of catalytic ozonation in a membrane reactor is proposed in the published development [18]. It is also recommended to reduce the volume of the leachate of landfill sites by increasing the level of transpiration by specially selected plants [19]. As sorbents for cleaning the leachate, it is possible to use a chemically modified tripoli, activated carbon [20, 21].

Most of the developed methods are expensive, and therefore the 
use of ferric-silicon coagulant-flocculant (FSCF of electric steel smelting slag of «OMK-Steel» JSC (Vyksa, Nizhny Novgorod region, RF) is promising. In the previously published paper it was given physical and chemical properties of slag, it was determined optimal parameters of acid modification of hydrochloric acid slag; the concentrations of iron and silicon ions in suspension, $\mathrm{pH}$ of the medium. It is shown that the necessary content of iron and silicon in the production solution can be reached when the slag is opened, treated for 60 minutes at $40{ }^{\circ} \mathrm{C}$, the concentration of hydrochloric acid is $1.5 \mathrm{~N}$, which corresponds to a $\mathrm{pH}$ of the suspension equal to 0.65 . With these parameters, the concentration of silicic acid (according to $\mathrm{Si}$ ) is up to $1700 \mathrm{mg} / \mathrm{l}$, and the concentration of iron is up to $1250 \mathrm{mg} / \mathrm{l}$ [22].

\section{Material and Methods}

\subsection{Filtration water of the leachate landfill of commu- nal solid waste}

The leachate was selected in May 2017 at the communal solid waste landfill in Belgorod (the RF). Its characteristics is given in Table 1. Toxicological studies with the use of two test objects showed that it is classified as the third hazard class according to the federal waste classifier (Table 2). According to the environmental legislation, the leachate is classified as a group of wastes generated at the disposal of the communal wastes.

Table1 : Physical and chemical composition of the filtration water at the communal waste leachate landfill $(\mathrm{pH}=8.64)$

\begin{tabular}{|c|c|c|}
\hline № № & Component & Content \\
\hline 1 & Ammonium nitrogen, $\%$ & 0.036 \\
\hline 2 & Calcined residue, $\%$ & 0.41 \\
\hline 3 & Suspended solids, $\mathrm{g} / \mathrm{dm}^{3}$ & 413.0 \\
\hline 4 & $\mathrm{COD}, \mathrm{mg} \mathrm{O} / \mathrm{dm}^{3}$ & 8420.0 \\
\hline 5 & $\mathrm{BOD}_{5}, \mathrm{mg} \mathrm{O}_{2} / \mathrm{dm}^{3}$ & 2745.6 \\
\hline 6 & Coloration, degrees & 10366 \\
\hline 7 & Nitrate nitrogen, \% & 0.056 \\
\hline 8 & Density, $\mathrm{g} / \mathrm{cm}^{3}$ & 0.998 \\
\hline 9 & Sulfates, \% & 0.26 \\
\hline 10 & Phosphate, $\%$ & 0.031 \\
\hline 11 & Chlorides, \% & 0.46 \\
\hline 12 & Chrome, \% & 0.0046 \\
\hline 13 & Zink, \% & 0.01 \\
\hline 14 & Natrium, \% & 0.25 \\
\hline 15 & Aluminum, \% & 0.05 \\
\hline 16 & Potassium, \% & 0.07 \\
\hline 17 & Temperature, ${ }^{\circ} \mathrm{C}$ & 20 \\
\hline 18 & Iron, \% & 0.218 \\
\hline 19 & Cadmium, \% & 0.0001 \\
\hline 20 & Calcium, \% & 0.020 \\
\hline 21 & Magnesium, \% & 0.008 \\
\hline 22 & Copper, \% & 0.098 \\
\hline 23 & Nickel, \% & 0.004 \\
\hline 24 & Lead, \% & 0.001 \\
\hline 25 & Phenylic acid, \% & 0.0023 \\
\hline 26 & Dry residue, $\%$ & 0.59 \\
\hline
\end{tabular}

Table 2: The toxicological analysis data of the liquid waste «The leachate of the communal solid wastes landfill is reasonably dangerous»

\begin{tabular}{|c|c|c|c|c|}
\hline \multirow{2}{*}{$\begin{array}{l}\text { Method / test } \\
\text { length, hours }\end{array}$} & \multirow[t]{2}{*}{ Test object } & \multicolumn{3}{|c|}{ Target parameter } \\
\hline & & \multicolumn{2}{|c|}{$\begin{array}{l}\text { Acute (chronic) } \\
\text { toxic effect }\end{array}$} & $\begin{array}{l}\text { Dilution } \\
\text { factor, } \\
\text { times }\end{array}$ \\
\hline \multirow{4}{*}{$\begin{array}{l}\text { Mortality } \\
\text { and fertility } \\
\text { test / } 48 \\
\text { The testing } \\
\text { culture opti- } \\
\text { cal density } \\
\text { measurement } \\
\text { / } 22\end{array}$} & \multirow{2}{*}{$\begin{array}{l}\text { Ceriodaphnia } \\
\text { affinis }\end{array}$} & presence & $\mathrm{LDF}^{\mathrm{a}}{ }_{50-48}$ & 100 \\
\hline & & absence & $\operatorname{SDF}^{\mathrm{b}}{ }_{10-48}$ & 1000 \\
\hline & $\begin{array}{l}\text { Chlorella } \\
\text { vulgaris }\end{array}$ & presence & $\operatorname{IDF}^{\mathrm{c}}{ }_{50-22}$ & 100 \\
\hline & Beijer & absence & $\mathrm{SDF}_{20-22}$ & 1000 \\
\hline
\end{tabular}

Fig. 1 shows the results of its phytotoxicity on the root system of Allium cepa (exposure was performed in test tubes). The leachate under study was formed during the exploitation of the leachate landfill, which has been operating for more than 10 years. From Table 1 it follows that with such high values of COD and $\mathrm{BOD}_{5}$, as well as coloration (it has a dark brown color), the most acceptable is its physical and chemical treatment with the use of coagulants and flocculants. The lethal multiplicity of the leachate dilution, at which an acute toxic effect occurs, causing the death of $50 \%$ of two test objects in 48 or 22 hours of the exposition, is a dilution of 1: 100 (Table 2). In the leachate without dilution (Fig. 1) the growth of the roots of Allium cepa is practically absent, with dilution by $10 ; 100$ and 1000 times it is inhibited compared to the control sample (running water).

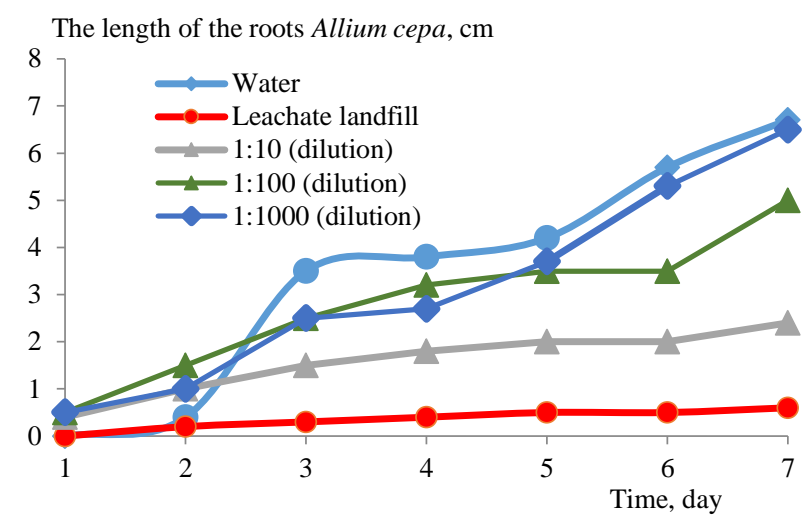

Fig. 1: Influence of the filtration water dilution multiplicity on the growth of the root system Allium cepa

\subsection{The ferric-silicon coagulant-flocculant (FSCF) of the electrical steel smelting slag}

The coagulant-flocculant was obtained by acidizing the slag under the above conditions, then the liquid part was separated from the si-stoff and used to purify the filtration waters. The chemical oxide composition of the electric steel smelting slag is determined by $\mathrm{X}$-ray diffraction analysis using the roentgen-fluorescent spectrometer Scientific ARL 9900 WorkStation and consists of: $\mathrm{CaO}$ 35,$4 ; \mathrm{Fe}_{2} \mathrm{O}_{3}-25,8 ; \mathrm{SiO}_{2}-17,06 ; \mathrm{MgO}-8,9 ; \mathrm{Al}_{2} \mathrm{O}_{3}-6,4 ; \mathrm{MnO}-$ 3,$6 ; \mathrm{Cr}_{2} \mathrm{O}_{3}-1,12 ; \mathrm{Na}_{2} \mathrm{O}-0,69 ; \mathrm{P}_{2} \mathrm{O}_{5}-0,312 ; \mathrm{TiO}_{2}-0,198 ; \mathrm{SO}_{3}-$ 0,$176 ; \mathrm{Cl}-0,094 ; \mathrm{V}_{2} \mathrm{O}_{5}-0,081 ; \mathrm{BaO}-0,065 ; \mathrm{SrO}-0,03 ; \mathrm{WO}_{3}-$ 0,027; $\mathrm{CuO}-0,019 ; \mathrm{K}_{2} \mathrm{O}-0,012 ; \mathrm{CO}_{3} \mathrm{O}_{4}-0,009 ; \mathrm{NiO}-0,004$; $\mathrm{ZnO}-0,003$. The mineralogical composition was determined on a «Dron-2.0» X-ray diffractometer and was represented by such minerals with the following content: calcium silicate $\mathrm{Ca}_{2} \mathrm{SiO}_{4}-$ up to $19.4 \%$; ferromagnetic silicate $\mathrm{Mg}_{1{ }_{4} 1} \mathrm{Fe}{ }{ }_{59}\left(\mathrm{SiO}_{4}\right)$ - up to $9.4 \%$; aluminate diopside $\mathrm{Ca}(\mathrm{Mg}, \mathrm{Al})(\mathrm{Si}, \mathrm{Al})_{2} \mathrm{O}_{6}-$ up to $8.7 \%$; fayalite $\mathrm{Fe}_{2+2} \mathrm{SiO}_{4}$ - up to $5.7 \%$. Hydrochloric acid, as the stronger one, has a higher dissociation constant than that of orthosilicic acid $\left(\mathrm{K}_{\mathrm{a}}=1 \cdot 10^{7}\right)$ and displaces silicates from the minerals of the slag, which dissolve and go into the solution. The determination of the total mass concentration of silicon in the suspension was carried out photometrically as a yellow form of molybditesilicic acid at a wavelength of $410 \mathrm{~nm}$.

\subsection{Ferric and aluminum coagulants}

$20 \%$ water solutions of calcium sulfate and ferric chloride were used in the work by introducing separately into the filtration water or together with the FSCF.

\section{Results and discussion}

The optimum dose of the FSCF was determined experimentally together with a coagulant $-20 \%$ ferric chloride solution $\mathrm{FeCl}_{3}$ by trial coagulation under strictly defined experimental conditions. 
The resulting FSCF should accelerate the flocculation process and sedimentation of the formed coagulant flakes.

To study the efficiency of the filtration water treatment after clarification, $\mathrm{pH}$ was measured on an ionomer, coloration by a photometric method at a wavelength of $413 \mathrm{~nm}$ (l cuvettes $=50 \mathrm{~mm}$ ). It should be noted that the advantage of introduction of a flocculant to the coagulant is obvious, because the treatment efficiency increases, the opalescence disappears, the color of the treated water, observed with the use of one ferric chloride, decreases. The dose of a coagulant was according to $\mathrm{FeCl}_{3}=100$ and $200 \mathrm{mg} / \mathrm{l}$. A 250 $\mathrm{ml}$ of aliquot of the leachate was measured into the flasks, then the above doses of the coagulant were introduced and the FSCF in an amount of 1.5 to $21.0 \mathrm{mg} / \mathrm{l}$ was added. Then the leachate in the flasks was stirred within 30 minutes, then it was poured into the cylinders, followed by measuring the volume of the precipitate, COD values and the color of the clarified leachate. FSCF successfully reduces the color of the leachate due to the co-precipitation of humic acids. With increasing the dose of coagulant $\mathrm{FeCl} 3$ and FSCF, the efficiency of COD purification increases and the coloration decreases. Comparing the efficiency of purification at identical doses for $\mathrm{Al}_{2} \mathrm{O}_{3}$ and variable concentrations of active silicic acid (Fig. 2-5), it was determined that the presence of active silicic acid in the system provides a more complete purification of the filtration water from pollutants at doses of $\mathrm{FeCl}_{3} 200$ $\mathrm{mg} / \mathrm{l}$. It is noticed dependence of the treatment depth on the concentration of the flocculant. In the leachate the active silicic acid provides flocculation of the primary aggregates formed by positively charged ferric hydroxocomplexes and the particles of the suspended matters that carry a negative charge on their surface.

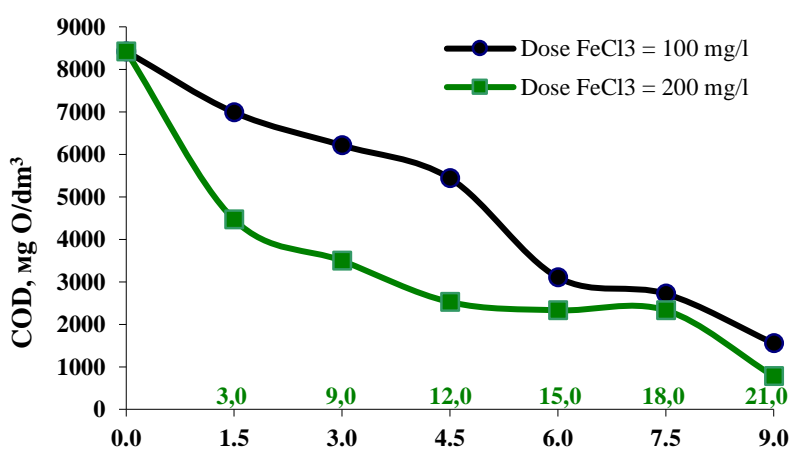

Dose of silicic acid $(\mathrm{Si}, \mathrm{mg} / \mathrm{l})$ at the dose of $\mathrm{FeCl}_{3}=100 \mathrm{mg} / \mathrm{l}$

Dose of silicic acid $(\mathrm{Si}, \mathrm{mg} / \mathrm{l})$ at the dose of $\mathrm{FeCl}_{3}=200 \mathrm{mg} / \mathrm{l}$

Fig. 2: Dependence of changes in COD values $\left(\mathrm{mg} \mathrm{O} / \mathrm{dm}^{3}\right)$ of the filtration water on the dose of the injected FSCF and the ferric chloride coagulant

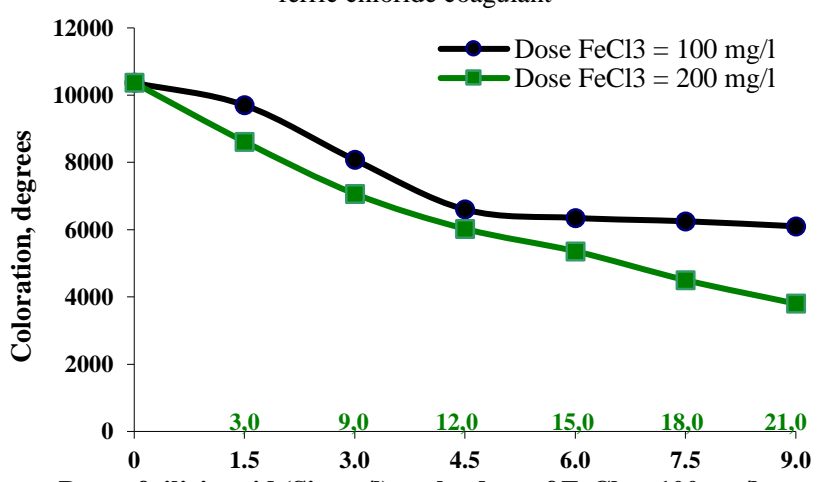

Dose of silicic acid $(\mathrm{Si}, \mathrm{mg} / \mathrm{l})$ at the dose of $\mathrm{FeCl}_{3}=100 \mathrm{mg} / \mathrm{l}$

Dose of silicic acid $(\mathrm{Si}, \mathrm{mg} / \mathrm{l})$ at the dose of $\mathrm{FeCl}_{3}=200 \mathrm{mg} / \mathrm{l}$

Fig. 3: Dependence of changes of coloration (degrees) of the filtration waters on the dose of the injected FSCF and the ferric chloride coagulant

The dark brown color of the filtration waters is due to the presence of humic matters, which in the aqueous solution are negatively charged due to the functional groups (carbonyl, ketone, phenolic, etc.). Coagulation of the humic matters occurs due to the interaction of these functional groups with positively charged iron hy- droxocomplexes, which are formed by the following hydrolysis equations:

$$
\begin{aligned}
& \mathrm{Fe}^{3+}+3 \mathrm{H}_{2} \mathrm{O} \leftrightarrow \mathrm{Fe}(\mathrm{OH})_{3}+3 \mathrm{H}^{+} ; \\
& \mathrm{Fe}(\mathrm{OH})_{3}+\mathrm{H}_{2} \mathrm{O} \leftrightarrow\left[\mathrm{Fe}(\mathrm{OH})_{4}\right]^{-}+\mathrm{H}^{+} ; \\
& 2 \mathrm{Fe}^{3+}+3 \mathrm{H}_{2} \mathrm{O} \leftrightarrow\left[\mathrm{Fe}_{2}(\mathrm{OH})_{3}\right]^{3+}+3 \mathrm{H}^{+} ; \\
& 2 \mathrm{Fe}^{3+}+5 \mathrm{H}_{2} \mathrm{O} \leftrightarrow\left[\mathrm{Fe}_{2}(\mathrm{OH})_{5}\right]^{+}+5 \mathrm{H}^{+} ; \\
& 3 \mathrm{Fe}^{3+}+2 \mathrm{H}_{2} \mathrm{O} \leftrightarrow\left[\mathrm{Fe}_{3}(\mathrm{OH})_{2}\right]^{7+}+2 \mathrm{H}^{+} ; \\
& 3 \mathrm{Fe}^{3+}+4 \mathrm{H}_{2} \mathrm{O} \leftrightarrow\left[\mathrm{Fe}_{3}(\mathrm{OH})_{4}\right]^{5+}+4 \mathrm{H}^{+} .
\end{aligned}
$$

Coagulation requires large doses of a coagulant to form a volumetric precipitate of ferric hydroxide. The stability of humic colloids depends on the $\mathrm{pH}$ of the medium. With decreasing $\mathrm{pH}$, the stability decreases, which promotes adsorption. The decrease in the $\mathrm{pH}$ of the medium (Fig. 5) is explained by the fact that FSCF are introduced into the filtration waters, obtained after the acid treatment of the electric steel smelting slag. With an increase in its amount, the $\mathrm{pH}$ accordingly decreases.

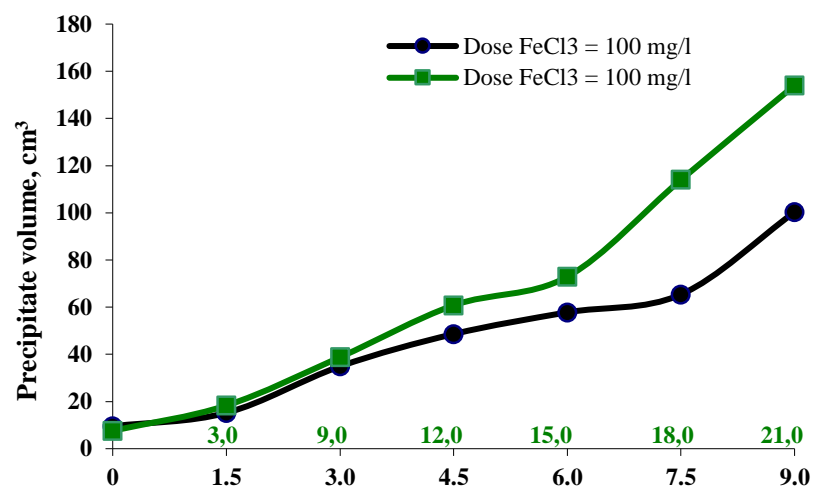

Dose of silicic acid $(\mathrm{Si}, \mathrm{mg} / \mathrm{l})$ at the dose of $\mathrm{FeCl}_{3}=100 \mathrm{mg} / \mathrm{l}$ Dose of silicic acid $(\mathrm{Si}, \mathrm{mg} / \mathrm{l})$ at the dose of $\mathrm{FeCl}_{3}=200 \mathrm{mg} / \mathrm{l}$

Fig. 4: Dependence of the change of the precipitate volume $\left(\mathrm{dm}^{3}\right)$ in the filtration waters after purification from the dose of the injected FSCF and ferric chloride coagulant

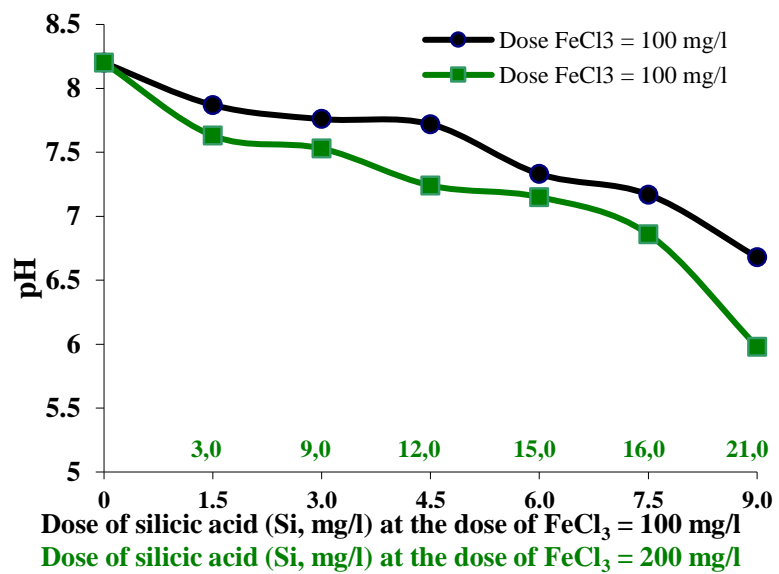

Fig. 5: Dependence of change of $\mathrm{pH}$ of the treated filtered water from the dose of the injected FSCF and ferric chloride coagulant

Chemical analysis of the dried FSCF was examined on a scanning electron microscope X-Max Oxford Instrument with an integrated $\mathrm{X}$-ray energy dispersive microanalyzer. The mineralogical composition was determined by X-ray diffraction analysis using the $\mathrm{X}$ ray fluorescence spectrometer Scientific ARL 9900 WorkStation. The elemental composition is given below in Table 3. The mineralogical composition is presented by such minerals as: Calcium Sodium Iron Magnesium Titanium Aluminum Silicate Diopsidejadeite, which is expressed by a complex formula $\left(\mathrm{Ca}_{0.47} \mathrm{Na}_{0.41} \mathrm{Fe}_{0.04} \mathrm{Mg}_{0.02}\right)\left(\mathrm{Mg}_{0.44} \mathrm{Fe}_{0.03} \mathrm{Ti}_{0.01} \mathrm{Al}_{0.52}\right)\left(\mathrm{Si}_{2} \mathrm{O}_{6}\right)$, Calcium chloride $\mathrm{CaCl}_{2}$ and Afwillite $\mathrm{Ca}_{3}\left(\mathrm{HSiO}_{4}\right)_{2} \cdot 2 \mathrm{H}_{2} \mathrm{O}$ (Fig. 6).

Table 3: The elemental composition of the FSCF

\begin{tabular}{c|c|c|c|c|c|c|c|c}
\hline $\mathrm{O}$ & $\mathrm{Mg}$ & $\mathrm{Al}$ & $\mathrm{Si}$ & $\mathrm{S}$ & $\mathrm{Cl}$ & $\mathrm{Ca}$ & $\mathrm{Mn}$ & $\mathrm{Fe}$ \\
\hline 11.08 & 0.54 & 0.45 & 11.09 & 0.12 & 37.32 & 27.99 & 0.22 & 11.19 \\
\hline
\end{tabular}


In order to increase the efficiency of the leachate treatment, it was carried out an experiment with the simultaneous injection of FSCF, ferric chloride and aluminum sulfate. The dosage of aluminum sulfate of $\mathrm{Al}_{2} \mathrm{O}_{3}$ was $20 ; 30$ and $40 \mathrm{mg} / \mathrm{l}$, the dose of $\mathrm{FeCl}_{3}-$ $30 ; 60 ; 90 ; 120$ and $150 \mathrm{mg} / \mathrm{l}$.

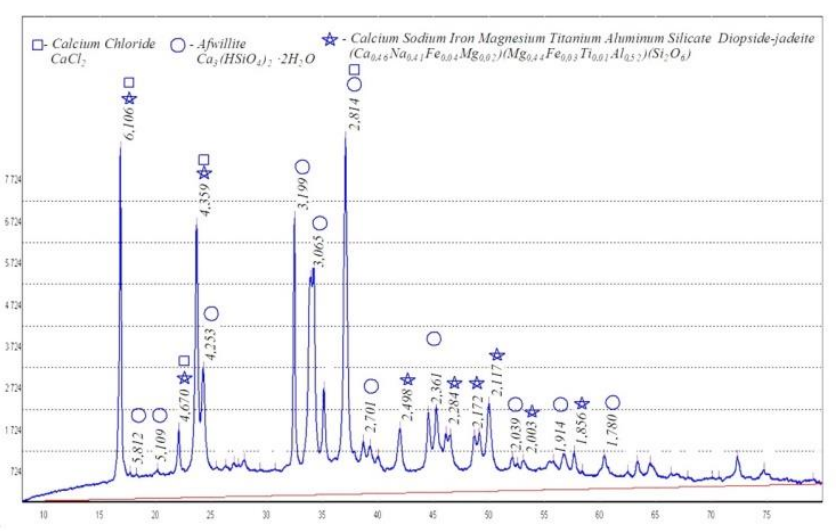

Fig. 6 : FSCF X-ray diffraction pattern

The treatment was carried out in the same way: first, the above dose of coagulants and then FSCF were injected into $250 \mathrm{ml}$ of the leachate under constant stirring. According to the literature, while treating colored waters, active silicic acid should be injected after the coagulant in not less than 10 seconds -3 minutes. When treating colored waters with a slight water turbidity, active silicic acid is injected up to $20 \%$ of the coagulant dose. After 30 minutes of stirring, the leachate was poured into the cylinders for decantation. The results are shown in Fig. 7-8. With an increase in the dose of coagulants and FSCF the COD values and the color of the leachate are reduced. The optimum doses of coagulants are 30 $\mathrm{mg} / \mathrm{l}$ for $\mathrm{Al}_{2} \mathrm{O}_{3}$ and $60 \mathrm{mg} / \mathrm{l}$ for $\mathrm{FeCl}_{3}, \mathrm{FSCF}-3.0-4.0 \mathrm{mg} / \mathrm{l}$ (of Si).

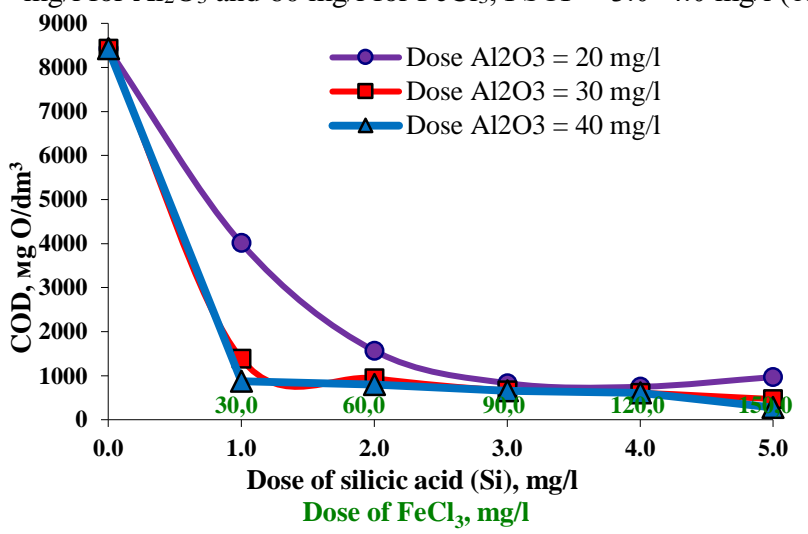

Fig. 7: Dependence of changes in COD values $\left(\mathrm{mg} \mathrm{O} / \mathrm{dm}^{3}\right)$ of the filtration waters on the dose of the injected FSCF and coagulants $\mathrm{FeCl}_{3}$ и $\mathrm{Al}_{2}\left(\mathrm{SO}_{4}\right)_{3}$

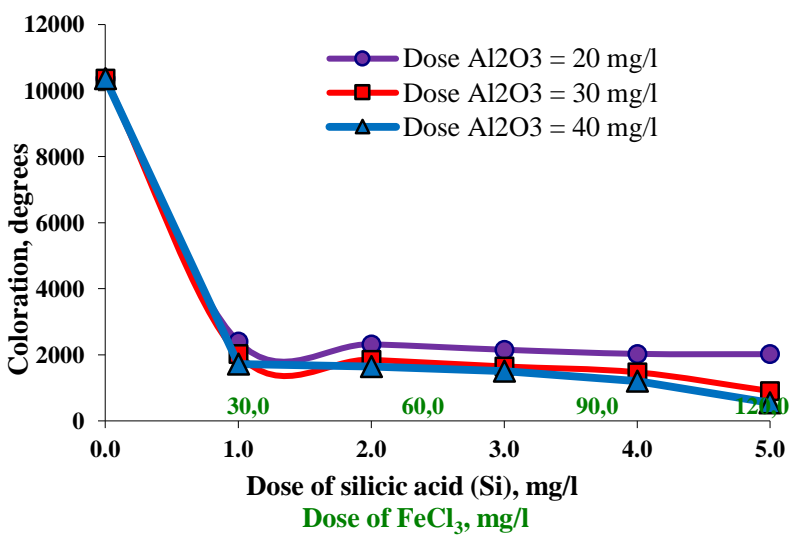

Fig. 8: Coloration dependence (degrees) of the filtration water from the dose of the injected FSCF and coagulants $\mathrm{FeCl}_{3}$ И $\mathrm{Al}_{2}\left(\mathrm{SO}_{4}\right)_{3}$
The $\mathrm{pH}$ values of the treatment process with three selected doses of the coagulant are in the range of 7.1-8.3. The process of coagulation with aluminum salts is recommended to be carried out at $\mathrm{pH}=4.5-8.0$, and for ferric chloride, the coagulation process is optimal at $\mathrm{pH}=7$.

\section{Conclusions}

The FSCF together with the test coagulants is recommended to be used while treating slightly turbid, highly colored waters, such as the leachate. The main stage in the process of gel formation during acid slag processing is the collision of two silica particles with a sufficiently low surface charge. The transition of $\mathrm{H}_{4} \mathrm{SiO}_{4}$ into the solution can be shown by the scheme:

$$
\left(\mathrm{SiO}_{2}\right)_{\mathrm{x}}+2 \mathrm{H}_{2} \mathrm{O} \rightarrow \mathrm{H}_{4} \mathrm{SiO}_{4}+\left(\mathrm{SiO}_{2}\right)_{\mathrm{x}-1}
$$

At the second stage dimeric particles with one equivalent of silicic acid are formed:

$$
\begin{aligned}
& 2 \mathrm{H}_{4} \mathrm{SiO}_{4} \rightarrow(\mathrm{HO})_{3} \equiv \mathrm{Si}-\mathrm{O}-\mathrm{Si} \equiv(\mathrm{OH})_{3}+\mathrm{H}_{2} \mathrm{O} \text { или } \\
& (\mathrm{HO})_{3} \equiv \mathrm{Si}-\mathrm{OH}+\mathrm{HO}-\mathrm{Si} \equiv(\mathrm{OH})_{3} \rightarrow(\mathrm{OH})_{3} \equiv \mathrm{Si}-\mathrm{O}-\mathrm{Si} \equiv(\mathrm{OH})_{3}+\mathrm{H}_{2} \mathrm{O}
\end{aligned}
$$

The silicic acid precipitating from the hydrolysis reaction contains silanol groups $(\equiv \mathrm{Si}-\mathrm{OH})$ capable of polycondensation reaction with formation of siloxane bonds ( $=\mathrm{Si}-\mathrm{O}-\mathrm{Si}$ ). The rate of gelation is maximal at pH 5.5-6.0. As soon as FSCF is obtained, it must be injected into the leachate. Comparing the efficiency of treatment at three chosen doses of $\mathrm{Al}_{2} \mathrm{O}_{3}$ and variable concentrations of FSCF and $\mathrm{FeCl} 3$, it can be stated that their simultaneous injection provides a more complete purification of the leachate from pollutants at a dose of $\mathrm{Al}_{2} \mathrm{O}_{3}$ over $20 \mathrm{mg} / \mathrm{l}$. The recommended optimal dose of the coagulants: $30 \mathrm{mg} / \mathrm{l} \mathrm{of} \mathrm{Al}_{2} \mathrm{O}_{3}$, and $60 \mathrm{mg} / \mathrm{l} \mathrm{of} \mathrm{FeCl}_{3}$; the dose of FSCF is $3.0-4.0 \mathrm{mg} / 1$ (of $\mathrm{Si}$ ), at which the coloration is reduced by $69 \%$, and the COD purification efficiency is up to $85 \%$. An important advantage of FSCF over polyacrylamide is the higher efficiency while treating at low temperatures and considerably low cost.

An application of FSCF for water treatment allows to accelerate the formation of flakes in the mixing chamber, their decantation in sedimentation tanks and increase the effect of water clarification at treatment plants. In the future such waters can be directed for the biological purification using water vegetation (reed, reed mace). The purification scheme is shown in Fig. 9. When choosing a filtration water purification technology, it is necessary to take into account the stage of the life cycle of the landfill and the capacity of the facility. The technological scheme for the filtration waters purification of the landfill includes: a storage tank; open hydrocyclone without inside devices; grout tank; a supply tank; baffle mixing basin; vertical precipitation tank; filter press; circulation pump; bioplato.

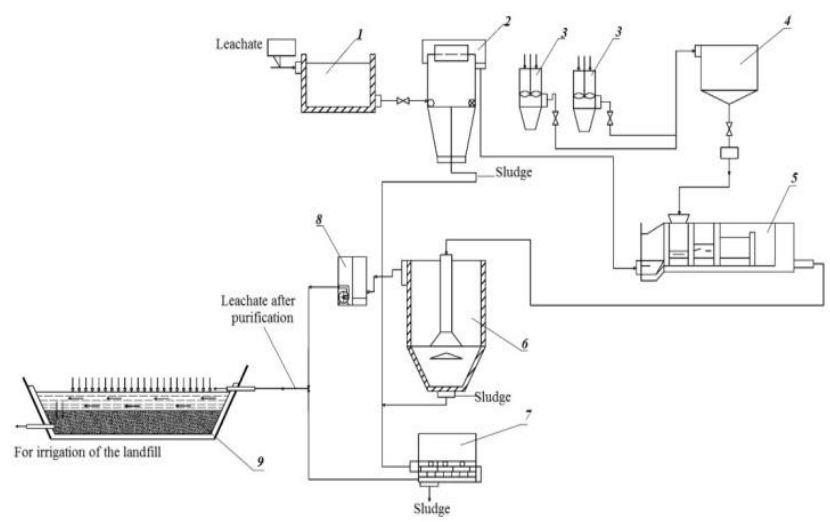

Fig. 9: The technological scheme of purification of the leachate:

1 - storage tank; 2 - open hydrocyclone without inside devices; 3 - grout tank; 4 - supply tank; 5 - baffle mixing basin; 6 - vertical precipitation tank; 7 - filter press; 8 - circulation pump; 9 - bioplato 


\section{References}

[1] Zharmenov AA, Myrzalieva SK, Aimbetova EO (2011), The use of waste electric steel melting for the production of protective composite materials. Glass-ceramics, No. 8, pp. 6-10.

[2] Panshin AM, Kozlov PA, Nesmelov VY (2013), Evaluation and potential possibilities on treatment of metals practice's waste. Ecology and Industry of Russia, No. 9, pp. 21-23.

[3] Leont'ev LI, Ponomarev VI, Sheshukov OYu (2016), Recycling and disposal of industrial waste from metallurgical production. Ecology and Industry of Russia, V. 20, No. 3, pp. 24-27.

[4] Kalmykova YS (2014), Ecology and Industry of Russia, No. 3, pp. 21-25.

[5] Ksenofontov BS, Kozodayev AS, Taranov PA, Vinogradov MS, Balina AA, Petrova EV (2013), Influence of ashes and slags preparation on rate of recovery of precious and rare earth metals from its. Ecology and Industry of Russia, No. 8, pp. 13-15.

[6] Kiryushina NY (2013), Peculiarities of purification of wastewaters of electroplating industries from ions of heavy metals by the slag of electric furnace steelmaking. Monthly Scientific Journal "Water Treatment", No. 6, pp. 44-58.

[7] Sukhanov EV, Svergunova SV, Shaihiev IG, Porozhnyuk LA, Fomina EV, Denisova LV (2016), Some of the features of coagulation treatment of water using a dust of electric steel production. Bulletin University of technology (KNRTU), Vol. 19, No. 9, pp. 158-163.

[8] Spiridonova LG (2015), purification of high- and medium concentrated sewage waters using various coagulant types manufactured out of industrial wastes. Monthly Scientific Journal "Water Treatment", No. 3, pp. 41-50.

[9] Sverguzova SV, Starostina IV, Sukhanov EV, Sapronov DV, Bulletin University of technology (KNRTU), Vol. 19, No. 3, pp. 113-115.

[10] Smirnov AD, Krouchinina NE, Burbayeva IV, Timasheva NA (2005), Ecology and Industry of Russia, No. 8, pp. 4-7.

[11] Vinnikova OS, Loukashov SV (2015), Determination of Optimal Preparation Conditions of Iron-Containing Coagulants by Oxidation of Spent Solutions Using Sodium Hypochlorite. Ecology and Industry of Russia. Vol. 19, No. 5, pp. 34-36.

[12] Sakita S, Nishimoto J, Nishimura K (2017), Porous Structure of Municipal Solid Waste Incineration Bottom Ash in Initial Stage of Landfill. Journal of Geoscience and Environment Protection, No. 5, pp. 9-20.

[13] Liu H, Konga S., Liu Y, Zeng H (2012), Pollution control technologies of dioxins in municipal solid waste incinerator. Procedia Environmental Sciences, No. 16, pp. 661-668.

[14] Yao P, Perspectives on technology for landfill leachate treatment. Arabian Journal of Chemistry, No. 10, pp. 2567-2574.

[15] Povorov AA, Pavlova VF, Shinenkova NA, Logunov OY (2008), Drainage water treatment of municipal solid waste landfills. Scientific and practical journal "Ecology for production", No. 11, pp. 54-56.

[16] Trifonova TA, Povorov AA, Shirkin LA, Selivanov OG, Il'ina ME (2015), Package technology of treatment of seepage waters at municipal solid waste landfills. Ecology and Industry of Russia, Vol. 19, No. 11, pp. 4-9.

[17] Povarov AA, Selivanova NV, Trifonova TA, Pavlova VF, Selivanov OG, Ilyina ME, Shirkin LA, Torshin VB (2014), Purification of leakage waters from solid household waste polygon. Proceedings of the Samara scientific center, Russian Academy of Sciences. V. 16 No. 1(3), pp. 661-664.

[18] Fattakhova AM (2015), Sewage water purification at waste landfills, use of catalysts ozonation in membrane reactor. Monthly Scientific Journal "Water Treatment", No. 5-6, pp. 39-49.

[19] Voronkova TV, Gracheva EV (2013), Reduction of leachate volume from solid municipal waste landfill-sites during periods after operation owing to transpiration level increase. Ecology and Industry of Russia, No. 11, pp. 34-37.

[20] RU $2401250 \mathrm{C} 1$. Method of cleaning filtrate of domestic landfill. Application: 2009134291/05, 15.09.2009. Date of publication: 10.10.2010 Bull. 28

[21] Fedosova TA, Roshina SI, Nikiticheva MS (2014), Sorption purification of seepage water from landfills. International Journal of Applied and Fundamental Research, No. 8, pp. 103-106.

[22] Vasilenko TA, Koltun AA (2017), Chemical aspects of the obtaining of iron-containing coagulant-flocculant from electric steel melting slag for wastewater treatment. Solid State Phenomena, Vol. 265, pp. 403-409. 